\title{
IfIISGUC.ORG
}

"ISS, GÜC̣" ENDÜSTRi iLISTKILERI VE INSAN KAYNAKLARI DERGISi

"IS, GUC" INDUSTRIAL RELATIONS AND HUMAN RESOURCES JOURNAL

\section{Örgütsel Bilginin Yönetimi ve Öğrenen Organizasyon Yazınındaki Yeri}

\author{
Organizational Knowledge Management and \\ Investigation in Learning Organization Literature
}

\author{
Dr. Metin ATAK
}

Hava Teknik Okullar Komutanlığı

Nisan/April 2011, Cilt/Vol: 13, Sayı/Num: 2, Page: 155-176

ISSN: 1303-2860, DOI: 10.4026/1303-2860.2010.0178.x

Makalenin on-line kopyasına erişmek için:

http://www.isguc.org/?p=article\&id=457\&vol=13\&num=2\&year=2011

To reach the on-line copy of article:

http://www.isguc.org/?p=article\&id=457\&vol=13\&num=2\&year=2011

Makale İçin İletişim/Correspondence to: 
(C) 2000- 2011

“İşGüç" Endüstri İlişkileri ve İnsan Kaynakları Dergisi

"İşGüç" Industrial Relations and Human Resources Journal

Nisan/April 2011, Cilt/Vol: 13, Say1/Num: 2

ISSN: 1303-2860, DOI: 10.4026/1303-2860.2010.178.x

Editör/Editor-in-Chief

Aşkın Keser (Kocaeli University)

Editör Yardımcıları/Co-Editors

K.Ahmet Sevimli (Uludağ University)

Gözde Yılmaz (Kocaeli University)

Uygulama/Design

Yusuf Budak (Kocaeli Universtiy)

\author{
Yayin Kurulu / Publishing Committee \\ Dr.Zerrin Firat (Uludağ University) \\ Doç.Dr.Așkm Keser (Kocaeli University) \\ Prof.Dr.Ahmet Selamoğlu (Kocaeli University) \\ Yrd.Doç.Dr.Ahmet Sevimli (Uludağ University) \\ Yrd.Doç.Dr.Abdulkadir Şenkal (Kocaeli University) \\ Yrd.Doç.Dr.Gözde Yilmaz (Kocaeli University) \\ Dr.Memet Zencirkıran (Uludă̆ University)
}

Uluslararası Danışma Kurulu / International Advisory Board

Prof.Dr.Ronald Burke (York University-Kanada)

Assoc.Prof.Dr.Glenn Dawes (James Cook University-Avustralya)

Prof.Dr.Jan Dul (Erasmus University-Hollanda)

Prof.Dr.Alev Efendioğlu (University of San Francisco-ABD)

Prof.Dr.Adrian Furnham (University College London-İngiltere)

Prof.Dr.Alan Geare (University of Otago- Yeni Zellanda)

Prof.Dr. Ricky Griffin (TAMU-Texas AEM University-ABD)

Assoc. Prof. Dr. Diana Lipinskiene (Kaunos University-Litvanya)

Prof.Dr.George Manning (Northern Kentucky University-ABD)

Prof. Dr. William (L.) Murray (University of San Francisco-ABD)

Prof.Dr.Mustafa Özbilgin (University of East Anglia-UK)

Assoc. Prof. Owen Stanley (James Cook University-Avustralya)

Prof.Dr.Işık Urla Zeytinoğlu (McMaster University-Kanada)

Danışma Kurulu / National Advisory Board

Prof.Dr.Yusuf Alper (Uludağ University)

Prof.Dr.Veysel Bozkurt (Uludağ University)

Prof.Dr.Toker Dereli (Işık University)

Prof.Dr.Nihat Erdoğmuş (Kocaeli University)

Prof.Dr.Ahmet Makal (Ankara University)

Prof.Dr.Ahmet Selamoğlu (Kocaeli University)

Prof.Dr.Nadir Suğur (Anadolu University)

Prof.Dr.Nursel Telman (Maltepe University)

Prof.Dr.Cavide Uyargil (İstanbul University)

Prof.Dr.Engin Yildirum (Sakarya University)

Doç.Dr.Arzu Wasti (Sabancı University)

Dergide yayınlanan yazılardaki görüşler ve bu konudaki sorumluluk yazarlarına aittir.

Yayınlanan eserlerde yer alan tüm içerik kaynak gösterilmeden kullanılamaz.

All the opinions written in articles are under responsibilities of the outhors.

None of the contents published can't be used without being cited. 


\title{
Örgütsel Bilginin Yönetimi ve Öğrenen Organizasyon Yazınındaki Yeri
}

\author{
Organizational Knowledge Management and Investigation in \\ Learning Organization Literature
}

\author{
Dr. Metin ATAK \\ Hava Teknik Okullar Komutanlığ
}

\begin{abstract}
Özet:
Günümüzde örgütler, küreselleşmenin hızlandırdığı değişim ortamına ve yeni rekabet şartlarına ayak uydurabilmek için yeni yapılanmalara yönelmektedirler. Öğrenen organizasyon olma, bu noktada tüm örgütlerin ilgisini çekmektedir. Bunun nedeni; hızh değişim ortamı ve yeni rekabet şartlarına en uygun yaklaşım olarak "öğrenen organizasyon" ön plana çıkmasıdır. Öğrenen organizasyon, hem bilgiye ulaşma, yeni bilgi yaratma, bilgiyi kullanma, mobilize etme, hem de yeni bilgi ve kaynağı karar ve davranışlara yansıtarak örgütsel öğrenmede yetenekli örgüttür. Bu çerçevede bilgi yönetimi, örgütsel öğrenme ile birlikte örgütlerin önem vermeleri gereken iki önemli yetenektir. Bu araştırmada örgütsel bilgi yönetimi, bir süreç olarak ele alınarak detaylı olarak incelenmekte, ve öğrenen organizasyon yazınındaki yeri belirlenmeye çalışılmakta,, öğrenen organizasyon ile ilişkili ve birbiri içine geçmiş olan örgütsel öğrenme ve bilgi yönetimi kavramları arasındaki hiyerarşi ve ilişki irdelenmektedir. Araştırma, birbiri içine girmiş ve birbiri ile ilişkili örgütsel öğrenme, öğrenen organizasyon ve bilgi yönetimi kavramlarmı konumlandırması açısından yazına katkı sağlamaktadır.
\end{abstract}

Anahtar Kelimeler: Bilgi-Enformasyon-Data, Örgütsel Bilgi, Bilgi Yönetimi, Örgütsel Öğrenme, Öğrenen Organizasyon

\begin{abstract}
:
Currently, in order to keep up with the new competition conditions and the changing patterns accelerated by globalization, organizations head towards new structures. At this very point being a learning organization arouses the interest of all the organizations because learning organization is in the most important place as an approach fitting the new competition conditions and rapid change patterns. Learning Organization is skilled at organizational learning in not only attaining, creating, using, mobilizing the knowledge but also reflecting this knowledge and source to its decisions and behavior. In this sense knowledge management together with organizational learning are the two important abilities that organizations need to pay attention. In this research, organizational knowledge management is examined as a process in details and its position in the literature of learning organization is tried to be determined. Also in this research, the hierarchy and relation between the two concepts as learning organizational within knowledge management related to organizational learning, is criticized. This study contributes to the literature in placing organizational learning, learning organization and knowledge management concepts which are related and within each other
\end{abstract}

Key Words: Knowledge-Information-Data, Organizational Knowledge, Knowledge Management, Organizational Learning, Learning Organization. 


\section{1. Öğrenen Organizasyon Kavramı.:}

Garvin'e göre öğrenme olmadan örgütler ve bireyler sadece eski deneyimleri ve uygulamaları tekrar ederler. Değişim bir maske gibi yatay kalır, iyileşmeler ya rastlantılar sonucu ya da kısa ömürlü olurlar (Garvin, 1993:78). Gerçekten bir örgüt yeni bir şeyler öğrenmeden gelişemez. Sorunları çözmek, yeni ürün ve süreçler geliştirmek farklı bakış açılarını gerektirir. Öğrenme olmadan, insanlar ve örgütler eski davranışlarını devam ettirmekten öteye geçemeyecekler ve değişemeyeceklerdir. Bu durumda değişim, kalite uygulamaları ve değişim çabaları şeklinde kalacak, öze inemeyecek ve yapılan iyileştirmeler ise belli bir temele oturmayan rastlantısal sonuçlar olarak kalacaktır.

Peter Senge, öğrenen organizasyonu, “İnsanların gerçekten çok istedikleri sonuçları yaratmak için, kapasitelerin sürekli arttırıldığı, yeni fikirlerin desteklendiği, ortak isteklerin serbestçe tartışıldığ 1 ve insanların sürekli olarak nasıl öğreneceklerini beraberce öğrendikleri organizasyonlardır" şeklinde tanımlamaktadır (Senge, 1990:11). Senge'den sonra yapılan çalışmalarda farklı birçok tanımlar yapılmış ve öğrenen organizasyon farklı şekillerde tanımlanmıştır. Garvin (1993)'e göre öğrenen organizasyon; "bilgi yaratma, elde etme ve aktarma yeteneğine sahip ve aynı zamanda davranışını, yeni bilgi ve görüşleri yansitabilecek şekilde düzenleme yeteneğine sahip organizasyondur". McGill ve Slocum (1993)'a göre öğrenen organizasyon; kendi tecrübelerinden etkili olanları bularak örgüte uyarlayan ve bu süreçte öğrenmeyi gerçekleştiren örgüttür. Thurbin'e göre, öğrenen organizasyon, üyelerinin bireysel olarak öğrenmesine ortam yaratarak ve onların öğrenmesinden yararlanarak, bilgisini, kendi anlayışı ve çevresini zaman içinde geliştirebilen organizasyondur (Arslan, 2001:68). Dibella ve Nevis'e göre, öğrenen organizasyon, organizasyondaki davranış değişimlerine tecrübe ile cevap veren ve çevresinde oluşan değişimlere uyum sağlamak için gereken yeteneğe sahip olan organizasyon olarak tanimlanir (Çorbacıŏglu, 2000:37). Marquardt ve Rey- nold'a göre öğrenen organizasyon, yeni bilgi, ürün ve hizmetler yaratan, organizasyonun içinde ve dişında yenilikçi ilişkiler kuran, daha geniş bir dünyanın aydınlanması ve daha yüksek bir amaca hizmet etmek için çalışan, yetkilendirilmiş bireyler grubudur (Özer, 2005:5-21). Pedler ve arkadaşları öğrenen organizasyonu; tüm çalışanların öğrenmesini kolaylaştıran ve kendini sürekli dönüştürebilen örgütler olarak tanımlamaktadır (Pedler ve diğ., 1991:1).

Tanımlar incelendiğinde öğrenen organizasyonla ilgili sürekli öğrenme, örgütsel öğrenme, değişim ve gelişim, bilginin elde edilmesi gibi ortak kavramların yer aldığ 1 görülmektedir. Bu durumda öğrenen organizasyonu; sürekli bilgi yaratan, bu bilgileri örgütün bilgisi haline getiren, paylaşım yoluyla davranışlarına yansıtan ve örgütsel süreçlerde kullanan, böylece çevreye uyum gösteren, kolayca değişen ve gelişen yapıya sahip örgüt olarak tanımlayabiliriz.

Gerçekten öğrenen organizasyon; bilgi yaratma, elde etme, paylaşma ve bu bilgiyi ve yeni görüşleri değişimde kullanma sürecidir. Öğrenen organizasyon; örgüt çalışanlarının yeni bilgi yaratmalarını, bunu paylaşmalarını, bu bilgiyi örgütün bilgisi haline getirmelerini ve sorunların çözümünde kullanmalarını esas almaktadır (Atak ve Atik, 2007:64). Tanımların ortaya çıkardığ1 ortak nokta; öğrenen organizasyonların bilgiyi yönetebilme ve örgütsel öğrenme yeteneğine sahip örgütler olduğudur.

\section{2. Örgütsel Öğrenme:}

Bugün öğrenen organizasyonun sahip olduğu temel yeteneklerden biri olan örgütsel öğrenme, tüm örgütleri etkileyen hızlı değişimler nedeniyle çok önemli bir süreç olarak görülmektedir. Çünkü örgütler hayatta kalabilmek için yeni yollar öğrenmek zorundadırlar (Jones, 2001:367). Bir örgütün öğrenmesi demek; yeni bilgi yaratmaya imkan verecek ortam hazırlamak, geliştirilen yeni bilgiyi yeni düşünce ve sistem üretiminde kullanmak, buradan elde ettiği tüm beceriyi bir öğrenme fırsatı sayarak yeniden bilgi yaratmayı teşvik etmek demektir 
(Koçel, 2003:438).

Bu noktada öğrenen organizasyon ile örgütsel öğrenmeyi birbirinden ayıran noktaları ifade etmekte fayda bulunmaktadır. Öğrenen organizasyon; belirsizliğe, karmaş1klığa ve değişime tepki veren ve değişimde ben varım diyebilen örgüttür. Örgütsel öğrenme ise; çevredeki belirsizlik ve karmaşıklığa yanıt verebilme kapasitesini artırmak ile ilgilidir. Bu doğrultuda öğrenen organizasyonun, örgütün sistemi ve süreçlerine odaklanma ile ilgili olduğu, örgütsel öğrenmenin ise, bilginin ve becerilerin nasıl oluştuğu ve kullanıldığ 1 ile ilgili olduğunu söyleyebiliriz.

Tsang'a göre ikisi arasındaki fark; oluşmak ve oluşum arasındadır. Örgütsel öğrenme, örgütlerin öğrenen organizasyon haline gelmek adına öğrenme olayını tüm çalışanları içine alan, bilinçli, sistematik ve sinerjik bir tarzda geliştirmelerini ifade etmektedir. Öğrenen organizasyon, örgütsel öğrenmenin en üst aşamasıdır ki örgüt bu aşamada, tüm çalışanların katılımı ve gelişimi ile kendini sürekli olarak dönüştürebilme yeteneğini sergiler. Örgütsel öğrenme, örgüt içinde yer alan belirli türde faaliyetleri ifade etmekteyken, öğrenen organizasyon; kendine özgü ve özel bir çeşit örgütü anlatmaktadır. Bu çerçevede öğrenen organizasyon, örgütsel öğrenme de başarılı olan örgütlerdir (Budak ve Budak, 2004:74).

Örgütsel öğrenme konusundaki ilk araştırmacilardan olan Argyris'in "hata tespit ve düzeltme süreci" olarak tanımladığı (Yazıcı, 2001:91) örgütsel öğrenme tanımı, Senge'nin yaptığ 1 "ögrrenmenin temelinde zihniyet değişikliği yatmaktadır" (Senge, 1990:22) katkısı ile yön değiştirmiş ve bugün örgütsel hafıza ve bilgiyi de içine alan "bilginin elde edilmesi, paylaşılması, yorumlanması ve yeniden kullanmak ve değerlendirilmek üzere örgütsel hafizada saklanması süreci" (Huber, 1991:90) olarak tanımlanmaktadır.

Örgütsel öğrenme, bilginin eğitim ya da tecrübeyle kazanılmasından çok, örgüt içinde davranış, değer ve normların birlikte geliştirilmesidir, örgütsel öğrenme tüm çal1şanların aktif katılımını gerektiren bir süreç- tir. Ortak deneyimlere, kararlara, değerlere dayalıdır. Bu şekilde oluşan kolektif değer ve normlar, çalişan herkes tarafından paylaş1lır hale gelir. Örgütün ve çevresinin sürekli değişimini sağlayan örgütsel öğrenme, örgütü sürekli olarak daha iyi durumlara taş1yan ve sonu olmayan bir süreçtir. Nasıl her sonuç yeni bir problemi doğuruyorsa, örgütsel sorunlara getirilen çözümler de bir süre sonra yeni sorunların meydana gelmesine neden olacaktır. Burada örgütsel öğrenmenin temel özelliği devreye girer ki; bu özellik de sadece kendisini ve çevresini yenilemesi veya değiştirebilmesi değil, aynı zamanda bu değişimin sürekliliğini sağlayabilmesidir (Yazıcı, 2001:88-90).

Örgütsel öğrenmenin burada ifade edilen "bilginin örgütsel davranış, değer ve normlara yansıtılması" özelliği bilginin içselleştirilmesi anlamina gelmektedir ki bu noktada örgütsel öğrenme bilgi yönetiminin bir alt basamağ1 olarak değerlendirilebilir. Bilgi yönetimi ve bilgi yönetim süreci ayrıntılı olarak incelendikten sonra bu ilişki ortaya konmaya çalışılacaktır.

\section{Bilgi Yönetimi:}

Bilgi yaratılması sürecini yapısallaştıran yani kurumsal bir nitelik kazandıran örgütlerin, bilgiyi yönetebilen örgütler olarak bilgi çağının en önemli rekabet aracına sahip olacakları gerçeği, örgütsel bilginin yönetimini zorunlu kılmaktadır. Bu anlamda bilgi yönetimi, günümüz örgütlerinin üzerinde önemle durmaları ve yetenek kazanmaları gereken stratejik bir kavramdır.

Bilgi yönetiminde amaç; öncelikle değerli yeni bilgilerin belirlenmesi, bunların ilgili birimlere ulaştırılması ve bilgi birikiminin canlı tutulmasıdır. Yapılan iş ile ilgili yeni bilginin aranması, bulunması ve ona ulaşılması, bilginin kaydedilmesi ve doğru olarak kullanılması, diğger çalışanlara iletilmesi ve paylaşılması, güncellenmesi ve güncelliğini yitiren ve kullanılmayan bilgilerin arşivlenmesi bu anlamda bilgi yönetiminin faaliyet konularıdır (Taşkın ve diğ., 2005:313). Örgüt üyeleri arasındaki bilgi akışını geliştirerek bilgi kapasitelerini daha iyi kullanmak üzere 
odaklanmakta olan bilgi çağı örgütlerinin amacı; bilginin etkin şekilde yaygınlaştırılmasıyla rekabet avantajı kazanmaktır. Son on yılda bilgi teknolojilerindeki hızlı ilerlemeler ve dinamik küresel çevrenin etkisiyle bilgi, sürdürülebilir rekabet avantajını kolaylaştıran ve geliştiren çok önemli bir kaynak haline gelmiştir (Hunt, 2003:189).

Bilgi yönetimi; Öğrenen organizasyonun sahip olduğu önemli bir yetenektir. Bilgi yönetimi, örgütsel bir değer elde edecek şekilde bilginin elde edilmesi, değerlendirilmesi ve paylaşılmasıdır. Öğrenen organizasyonun temelinde bilginin üretilmesi ve paylaşılması düşüncesi yatmakta (Şerbetçi, 2001:337) olduğundan öğrenen organizasyon ile bilgi yönetimi, yapılan çalışmalarda birlikte zikredilmekte yada birlikte incelenmektedir. Garvin'in “Öğrenen organizasyon; bilgi yaratma, elde etme ve aktarma yeteneğine sahip ve aynı zamanda davranışını, yeni bilgi ve görüşleri yansıtabilecek şekilde düzenleme yeteneğine sahip organizasyondur" (Garvin, 1993:80) tan1mindan da öğrenen organizasyonun bilgiyi yönetebilme yeteneğine sahip örgüt olduğu sonucuna ulaşılmaktadır.

Maddi olmayan varlıklardan değer yaratma sanatı olarak nitelenen bilgi yönetimi, hayati önem taşıyan bilginin açı ve sistematik yönetilmesi ve bu bilginin yaratma, organize etme, dağıtma, kullanma ve işleme süreci ile birleștirilmesi olarak tanımlanmaktadır. Bilgi yönetiminde çok önemli bilgilerin bir süreç dahilinde açık ve sistematik bir şekilde yönetilmesi söz konusudur. Bilginin yönetilmesi bir süreç olarak ele alınd1ğında bilgi yönetimi; örgütlere problem çözme, dinamik öğrenme, stratejik planlama ve karar verme gibi faaliyetler için gerekli olan önemli enformasyon ve deneyimlerin bulunması, seçilmesi, organize edilmesi, dağıtılması ve transfer edilmesini sağlayan bir süreçtir (İpçioğlu ve Erdoğan, 2005:634).

Literatürde bilgi yönetimi ile ilgili birbirinden farklı çok sayıda tanım yer almaktadır. Tanımların çok olması bilgi yönetimi alanında çalışan araştırmacıların strateji, psi- koloji, işletme ve üretim mühendisliği gibi farklı alanlardan olmalarından kaynaklanmaktadır (Mc Adam ve Mc Creedy, 1999:93). Bu tanımlamalardan bazıları şunlardır; "Bir örgütün entelektüel sermayesini en etkin șekilde kullanma" (Guthrie, 2000:11), "Bilgi akışını yönetmek, bilgiyi ihtiyaç duyanlara iletmek ve hemen harekete geçmelerini sağlama" (Gates, 1999:227), "Bir örgütte rekabet için kolektif bilginin saptanması ve desteklenmesi" (Von Krogh, 1998:133), "Doğru bilginin, doğru zamanda, doğru kişilere iletilmesi, çalışanlarla bilginin paylaşılması ve örgütsel performansın iyileştirilmesi sürecinde enformasyonun harekete geçirilmesi konusunda yardımcı olunmasına yönelik bilinçli bir strateji" (O’Dell ve diğ., 2003:23), "Örgütsel hedeflere ulaşmak için bilginin dönüştürülmesini, yaratılmasını ve yayılmasını yönlendiren süreçler toplamı"(Gurteen, 1998:6).

Bilgi Yönetimini "bilgiyi yaratmak, elde tutmak, paylaşmak ve geliştirmek için kullanilacak yeni radikal bir yol" olarak tanımlayan Barutçugil (2002:50) aynı zamanda bilgi yönetimini, örgütsel amaçlara ulaşılması yönünde, bilginin kolektif ve sistematik olarak yaratılması, paylaşılması ve uygulanması için kişilere, takımlara ve tüm örgüte olanak sağlayan yeni bir disiplin olduğunu değerlendirmektedir.

Yapılan bu tanımlamalardan bilgi yönetiminin, değer ortaya koyma amacıyla bilginin yaratılması ve paylaşımını sağlayan bir strateji ve süreç olarak görüldüğü gözlenmektedir. Bu süreç bilginin yaratılması, iç ve dış kaynaklardan gelen bilginin değerlendirilmesi, elde edilen bilgiler ile yaratılan bilgilerin biçimlendirilmesi, saklanması ve paylaşımı gibi faaliyetleri kapsayan son derce karmaşık ve mücadele gerektiren bir iştir. Çünkü, bilgi dinamiktir, sürekli gelişir ve bugün geçerli olan bilgi yarın geçersiz olabilir (İşcan ve Naktiyok, 2005:89).

Bu açıklamalardan hareketle bilgi yönetimini; bir örgütte bilgi üretimi, depolanması, organize edilmesi, dağıtılarak ya da erişime açılarak paylaşımın sağlanması yoluyla; ör- 
gütsel bilgi kaynaklarının düzenlenmesi, etkin bir şekilde yönetilmesi ve kullanılarak örgütsel çıktılara dönüştürülmesi/örgütsel çıktılarda kullanılması süreci olarak tanımlayabiliriz.

\subsection{Bilgi Yönetimi Kavramın Gelişimi:}

Bilgi ve Bilgi Yönetimi kavramları psikoloji, sosyoloji, yönetim gibi farklı disiplinlerde yer alan birçok kişinin ilgisini çekmiştir ve çekmektedir. Bunlar arasında en çok dikkat çeken çalışmalar M. Polanyi, Karl E. Sveiby, Peter F. Drucker, Ikujiro Nonaka, Amrit Tiwana, Davenport ve Prusak ile C. Argyris'e ait çalışmalardır. Literatür incelendiğinde 1950'li y1llardan itibaren kapalı bilgi ve açık bilgi, bilgi yaratma süreci, örgütsel zekâ, entelektüel sermaye gibi konularda çalışmalar yapıldığ görülmektedir. Daha önce de ifade ettiğimiz gibi akademisyenlerin bir kısmının bilgi yönetimi çalışmalarını öğrenen organizasyon çalışmaları ile birlikte yürüttükleri ve konuyu birlikte inceledikleri görülmektedir. Bu noktada bilgi yönetimi ile öğrenen organizasyon kavramlarında yapılan çalışmaların birbirini tamamlar nitelikte olduğu görülmektedir.

Bilgi Yönetimi disiplininin gelişim sürecinde özellikle Peter Drucker ve Nonaka, örgütsel bilginin önemi ve yeni bilgi yaratma kabiliyetinin geliştirilmesi üzerine yaptıkları çalışmalarda çok durmuşlardır. Bu dönemde, Toffler (1994:17), zihin işi olmadan ekonomide hiçbir katma değer veya servetin yaratılamayacağını söylerken, Drucker (1993:139) ulusların refahının kaynağının beşeri bir şey olan bilgi olduğunu öne sürmüş ve bilgi işi ile bilgi işçisi terimlerini ilk kez kullanmıştır. Naisbitt (1994:22) ise bilgi çağının en önemli kaynağının artık sermaye değil bilgi olacağını ifade etmiştir. Onların ifade ettiği bu öngörüler bugün bir gerçek olarak yaşanmaktadır. Bilgi bu çağın en büyük değeri haline gelmiştir.

İnternetin bütün dünyada hızla yayıldığ 1 dönem olan 1990'l1 y1llarda, bilginin ve yönetiminin artan önemine ilişkin bu akademik girdiler, bazı yenilikçi firmaların sahip oldukları bilgiyi paylaşarak değişime tepki verebileceklerini ve rekabetçi avantaj elde edebileceklerini keşfetmesine yardımcı olmuştur. İletişim altyapılarındaki iyileştirmeler ve yazılım endüstrisinin gelişimi neticesinde de bilgi yönetimi, örgütler için önemli bir rekabet avantajı sağlayan faktör haline gelmiştir. Böylece, geçmişte konuşulan geleceğe dönük hayaller, küreselleşen dünyada gerçekleşmeye başlamıştır. Bu durum bilimsel çevrenin de dikkatini çekmiş, yapılan araştırmalar örgütlerin uygulayabileceği bir bilgi yönetim süreci oluşturmaya yönelmiştir.

İlk olarak, 1986 yılında Dr. Karl Wiig tarafından işletme literatürüne kazandırılan bilgi yönetimi, örgütsel performansı arttırmak için bilgiyi eyleme dönüştürmeye yönelik bilinçli bir strateji olarak görülmeye başlanarak üzerinde değişik çalışmalar yürütülmüştür. Aslında bilgi yönetimi, büyük ölçüde 1990'l1 yıllardaki büyük değişimlerin bir ürünüdür. Konunun bir bütün olarak incelenmesi ise Peter F.Drucker'n 1993'de yayınlamış olduğu "Post-Capitalist Society" kitabı ile başlamış, 1990'lı yıllarda bu konunun babası sayılabilecek Nonaka ve Takeuchi'nin "The Knowledge Creating-Company" kitabında üzerinde durdukları bilgi şirketi kavramı üzerine yaptıkları çalışmalarla gelişmiştir. Senge'nin 1990 yılında yayınlanan "The Fifth Discipline" kitabı ile sonraki yıllarda Davenport ve Prusak'ın iş dünyasında bilgi yönetimi çalışmaları da disiplinin farklı yönlerde gelişimini sağlamıştır. Bilimsel çevrenin bu katkılarının yanında, büyük işletmelerin farklı uygulamaları da disiplinin gelişmesine katkılar yapmıştır.

\subsection{Genel Olarak Veri, Enformasyon ve Bilgi Kavramı}

Örgütsel Bilgi Yönetim Sürecinin anlaşılmasına katkı sağlaması amacıyla öncelikle bilgi ve onunla ilişkili olan veri ve enformasyon kavramları ile örgütsel bilgi kavramlarını incelemekte fayda bulunmaktadır. Çok boyutlu bir kavram olması nedeniyle bilgi, değişik bağlamlarda değişik amaçlar için, farklı biçimlerde kullanılmaktadır. Bunlardan veri (data) ve enformasyon (informa- 
tion) kavramları, sık sık karıştırılmakta ve kimi zaman birbirinin yerine kullanılmaktadır. Bilgi (knowledge) kavramı da aşağı yukarı ilk bakışta aynı anlamı çağrıştırmaktadır. Ancak, bu üç terim anlam bakımından birbirlerinden farklıdır. Her biri bilgi işleme sürecinin değişik aşamalarında ortaya çıkan ürünlerdir. Bu açıdan bakıld1ğında veri; ham, işlenmeye hazır ama henüz işlenmemiş gerçek ya da sayı, rakam, gibi figürlerdir. Enformasyon ise, verilerin karar alma sürecine destek sunacak şekilde anlamlı ve kullanılır bir şekilde işlenmesiyle ulaşılan sonucu ifade eder (İraz, 2005:244).

Bhatt daha kısa ve öz olarak veriyi; genellikle işlenmemiş gerçekler, enformasyonu; verilerin bir düzen içinde ele alınması, bilgiyi ise; anlaml enformasyon olarak tanımlamıştır (Bhatt, 2001:69). Burada dikkat edilmesi gereken husus; bilgide veri ve enformasyonun tersine daima beşeri bir yönün olmasıdır. Kitapların içinde enformasyon bulunabilir, ancak bir kişi enformasyonu özümsediğinde ve kullanılabilir hale getirdiğinde enformasyon bilgi haline gelir. Bilgi; sezgi, anlayış, deneyim ve daha önce elde edilmiş enformasyon üzerine kuruludur (Daft, 2000:258).

Bilgi, belli bir düzen içerisindeki deneyimlerin, değerlerin, amaca dönük enformasyonun ve uzmanlık görüşünün, yeni deneyimlerin ve enformasyonun bir araya getirilip değerlendirilmesi için bir çerçeve oluşturan esnek bir bileşimdir. Bilgi bilenlerin beyninde ortaya çıkar ve orada uygulamaya geçirilir. Enformasyon veriden, bilgi ise enformasyondan insan tarafindan yap1lir (Davenport ve Prusak, 1998:27).

Bilgi türleri ve bilgi dönüşümlerinin değerlendirilmesi tanımlama ve kavramsallaştırma çabaları açısından yaşamsal önem taşımaktadır. Nonaka ve Takeuchi (1995:17)'nin modeli literatürde sinıflandırma ve dönüşümün incelenmesi açısından genellikle temel olarak kabul edilen bir modeldir. Bu modelde bilgi, bilgi felsefesi aç1sından iki ayrı sınıfta incelenmektedir; kapalı bilgi (tacit knowledge) ve açık bilgi (explicit knowledge). Kapalı bilgi, yüksek derecede kişisel olan bir bilgi türüdür. Bu tür bilgiyi formülleştirmek ve başkalarına iletmek zordur. Örneğin zanaatkârlıkta kullanılan bilgi ya da tencerenin dibini tutturmadan sütlaç yapmak için kullanılan bilgi kapalı bilgi olup deneyim ve becerileri içerir. Açık bilgi ise, bilimsel ve sistematiktir, başkalarına kolaylıkla iletilebilir ve başkalarıyla kolaylıkla paylaşılabilir. Örgütler için açık bilginin dağıtılması ve paylaşılması, kapalı bilginin ise; yeni değerler üretilmesi amacıyla elde edilmesi büyük önem taşır.

Günümüzde bilginin aşırı miktarda olması bir yönüyle bilgisizleşme olarak ifade edilen bilgi değersizliğini doğurmaktadır. Çünkü bilgi, zamanla değer kaybederek enformasyon veya veri haline dönüşebilmektedir. Ancak çevresel gelişmelere bağl1 olarak bilgi, daha da değerlenerek sezgiye de dönüşebilir. Kitap ve bilgisayarda yer alan bilgiyi açık bilgi, insanların deneyimine bağlı olarak beyinlerinde oluşmuş ancak herhangi bir yere kaydedilmemiş bilgiyi kapalı bilgi olarak tanımlandığına göre bilgiye ait değer zinciri Şekil 2.1'deki gibi oluşturulur (Wilson, 2000:13).

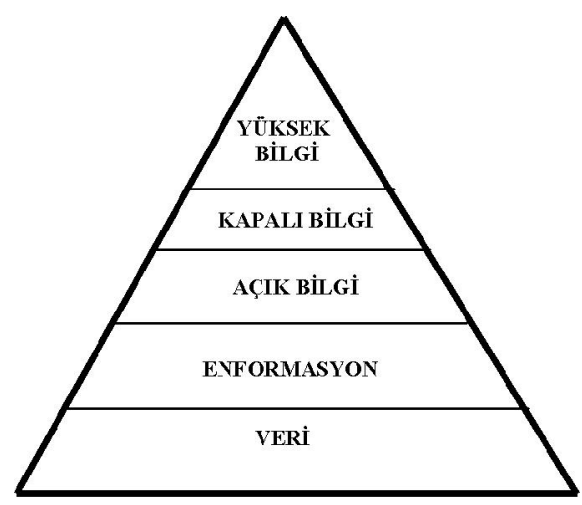

Şekil 1: Bilgi Değer Zinciri

\section{3. Örgütsel Bilgi Kavramı:}

Bilgi yönetimini ilgilendiren ve onun merkezinde yer alan bilgi örgütsel bilgidir. Bir örgütün sahip olduğu bilgi, bir bireyin 
sahip olabileceği bilginin çok üzerindedir. Bireyler örgüte gelir gider. Ancak örgüt bireylerin ötesinde bir örgütsel hafızaya, tarihe, bilgi donanımina sahiptir ve bunu aktarım yolu ile paylaşılır kılar (Geyik ve Barca, 2005:410). Örgütsel bilgi, bireysel bilgilerin basit bir toplamı olmayıp çalışanların sahip olduğu bilgiden farklı olarak herkes tarafından paylaşılan bilgidir. Örgütsel bilgi, örgütün misyonunu gerçekleştirirken kullanmak durumunda olduğu ortak bilgilerin bütünüdür.

Myers örgütsel bilgiyi; işlenmiş enformasyonun, yerleşmiş rutinler ve hareket dönüşümü süreçleri olarak tanımlamakta, örgütsel bilginin, örgütün kültürü, kuralları, ürünleri, süreçleri ve sistemleri kapsamakta olduğunu ifade etmektedir (Myers, 1996:2). Bhatt, benzer şekilde örgütsel bilginin; teknolojiler, teknikler ve insanlar arasındaki etkileşim kalıpları aracılığıyla oluşturulduğunu ve bu etkileşim kalıplarının örgütün kendine özgü geçmişi ve kültürü tarafından şekillendirildiğini söylemektedir (Bhatt, 2001:70). Davenport ve Prusak (2001:27) da bilgiyi tanımlarken bilginin, örgütlerde genellikle yalnızca bel- gelerde ya da dolaplarda değil rutin çalışmalarda, süreçlerde, uygulamalarda ve normlarda kendisini gösterdiğini ifade etmektedirler.

O halde örgütsel bağlamda bilgi; bir örgütün müşteri, ürün, süreç, organizasyon, başarı ve başarısızlık hakkında bildikleri veya organize edilmiş ve yapılandırılmış verileri olarak tanımlanabilir. Örgütsel bilgi örgütün; araştırma, gözlem veya deneyim yoluyla elde ettiği anlayıştır. Bu anlayış örgütsel açıdan anlamlı ve faydalı veriler yoluyla kazanılır (İşcan ve Naktiyok, 2005:85).

\section{Bilgi Yönetimi Süreci:}

Bilgi yönetimi genellikle, veri ve bilgi varlılarını toplama, organize etme ve paylaşma süreci olarak ifade edilmekle birlikte sadece bilgi elde etme, depolama ve organize etme süreci değildir. Aynı zamanda örgüt çapında öğrenme ve paylaşma yoluyla bilgi yaratılmasını da kapsamaktadır (Naktiyok, 2004:193). Bu durumda Bilgi Yönetimi, bir süreç olarak ele alındığında, örgütsel faaliyetler için gerekli olan bilginin bulunmasına, seçilmesine, organize edilmesine, yayılmasina ve transfer edilmesine, yeni bilgi yara-

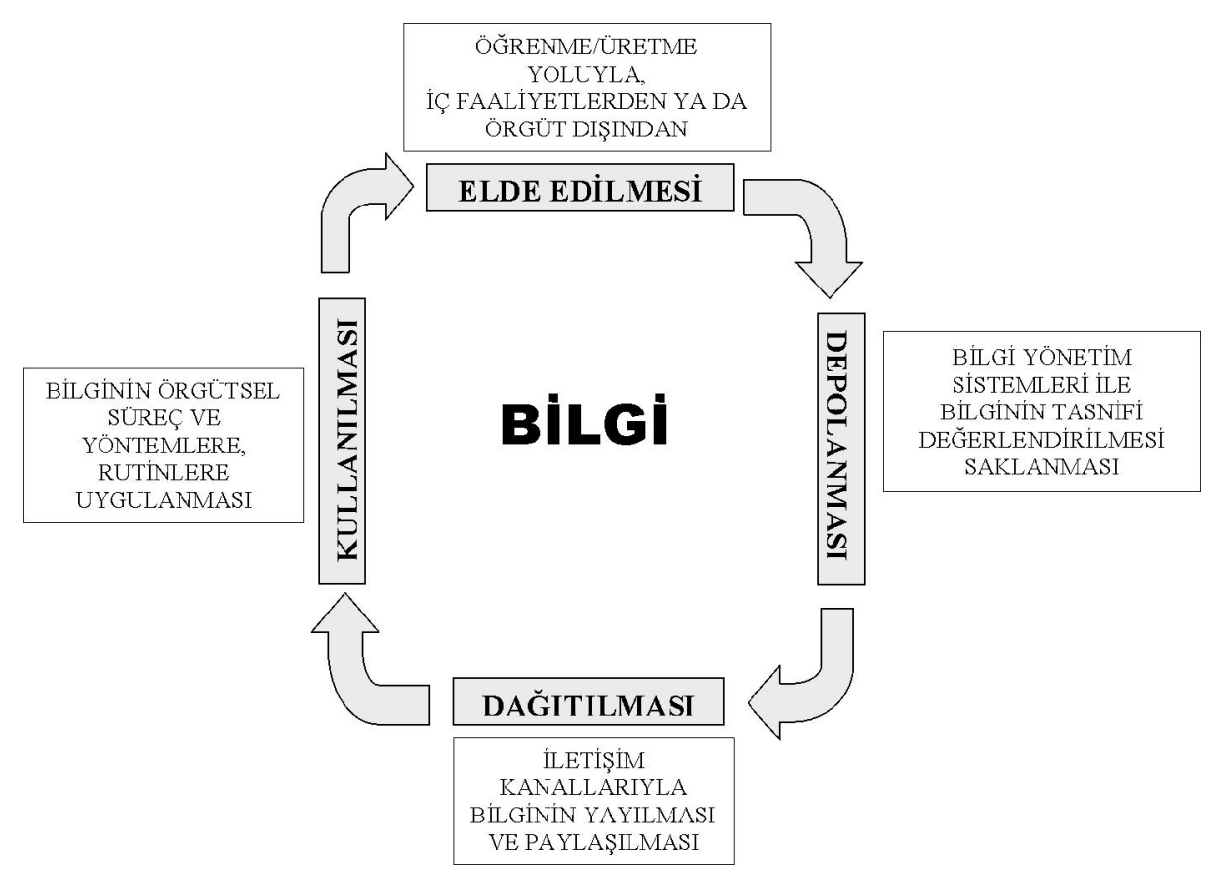

Şekil 2: Örgütsel Bilgi Yönetim Süreci 
tılmasına yardım eden bir süreç olarak ifade edilebilir (Gupta ve diğ., 1998:17). Benzer şekilde bir diğer tanımlama da bilgi yönetimini, bilginin açı ve sistematik olarak yönetilmesi ve bilginin yaratma, organize etme, dağıtma, kullanma ve işleme süreci ile birleştirilmesi olarak ifade etmektedir (Skyrme, 1999). Görüldüğü üzere örgütlerde bilgi yönetimi üzerine çalışan bir kısım araştırmacılar bilginin bir süreç halinde açık ve sistematik olarak yönetilmesine odaklanmişlardır. O halde bir disiplin olarak bilgi yönetiminin belli bir süreçten oluştuğunu söyleyebiliriz.

Bilgi yönetimi süreci; bilginin elde edilmesi/üretilmesi, bilginin depolanması/organize edilmesi, bilginin dağıtılması/ paylaşılması ve bilginin kullanılması/örgütsel süreçlere uygulanması basamaklarından oluşmaktadır (Bhatt, 2001:69; Davenport ve Völpel, 2001:219; Naktiyok, 2004:194).

Şekil 2.'de de görüleceği üzere bilgi yönetimi; bilginin örgüt içi ya da dışı kaynaklardan temin edilmesi, temin edilen bilginin tasnif edilmesi ve analizden sonra kullanima hazır hale getirilerek depolanması, ihtiyaç duyan kişi/birimlere dağıtılması ya da paylaşıma sunulması ile ilgili kişilerce alınan bilginin, örgütsel süreç ve yöntemlere uygulanarak yeni ürün ya da örgütsel bilgi üretilmesi şeklinde bir süreçten oluşmaktadır. Bundan sonraki kısımda süreç içerisinde yer alan adımlar incelenecektir.

\subsection{Bilginin Elde Edilmesi:}

Bilgi Yönetimi sürecinin ilk adımı bilginin elde edilmesidir. Çevresiyle sürekli etkileşim içinde olan bir örgüt çevresinden hem bilgi toplar hem de çevresine bilgi dağıtır. Örgütler müşterilerinden, toplumdan, eğitim ve araştırma kuruluşlarından hatta rakiplerinden çok önemli bilgi ve enformasyon elde ederler. Elde edilen bu bilgi bazen o kadar değerli olabilir ki, örgüt bu sayede olağanüstü verimlilik artışları, maliyetlerde büyük ölçüde düşüşler, yeni müşteri ya da pazar olanakları, ürün ve süreç yenilikleri gibi rekabet avantajları sağlayabilirler (Durna, 2005:75). Örgütler bilgiyi aynı za- manda kendi iç dinamiklerinden de elde ederler. Bilgi, örgütün bilgi sistemlerindeki veri tabanlarında yer alabileceği gibi, tecrübeler yoluyla elde edilen ya da öğrenilen bilgiler de olabilir.

Bilgiyi elde etmenin günümüzde kullan1lan diğer bir etkili yolu da onu doğrudan satın almaktır. Yani bilgiye sahip olan başka bir işletmeyi satın almak, nitelikli insanları işe almak ya da know-how gibi direk kullanılabilecek bilgiyi satın almaktır (Davenport ve Prusak, 1998:86). Ancak, bilgi ne kadar hazır olursa olsun onu kullanabilmek ve örgütsel süreçlere uygulayabilmek için örgüte uyumunu sağlamak gerekecektir.

Elde edilen bilgi çoğu zaman üst bilgiye/örgütsel bilgiye dönüştürülecek veri, enformasyon ve bilgiden oluşur. Her ne şekilde elde edilirse edilsin elde edilen bilgi, duruma göre o örgüt için veri, enformasyon ya da bilgi şeklinde kalacaktır. Burada önemli olan elde edilen bilginin örgütsel bilgiye dönüştürülmesidir. Örgütler iç ve dış çevreleri ile ilişkileri sırasında ihtiyaç duydukları bilgiyi alarak kendi tecrübeleri, prosedürleri, değerleri ve kuralları ile birleştirerek bilgiye dönüştürürler. $\mathrm{Bu}$ da ancak bilgi üretim sürecinin işletilerek elde edilen bilginin kapalı bilgiyi açık bilgi haline dönüştürülmesinde kullanılması ile mümkün olabilmektedir.

Örgütlerdeki bilgi elde etme faaliyeti bilgi üretim süreci ile de desteklenmektedir. Bu nedenle bilgi üretim sürecini de ayrıca incelemekte fayda bulunmaktadir.

Bilgi üretim süreci 3 temel bileşenden oluşmaktadır. Örgütsel bilgi yaratılmasına bir model olarak önerilen bu sürecin bileşenleri şunlardır (Nonaka ve diğ. 2000:8);

- Açık ve kapalı bilgi arasındaki dönüşüm ile bilgi yaratma (SECI),

- Bilgi üretimi için paylaşılan ortam (BA),

- Bilgi üretim sürecinin girdi, çıktı ve uyumlaştırıcılarıdır (Bilgi Varlıkları).

\section{4..1.1. SECI Süreci}

Daha önce de ifade ettiğimiz gibi örgüt- 
sel bilgi açık ve kapalı olmak üzere 2 farklı bilgiden oluşmaktadır. Açık bilgi örgütün bilgi sistemlerinde, dokümanlarında, iş süreçlerinde, prosedürlerinde yer almakta olup ulaşılması kolaydır. Kapalı bilgi ise; tamamen çalışanların beyninde, tecrübelerinde gizli olan kişisel bilgidir. Örgütsel bilgi üretiminde temel varsayım, kapalı bilginin açık bilgiye dönüştürülmesidir.

Birbirini tamamlamakta olan açık bilgi ile kapalı bilgi insanların yaratıcılık eylem süreçlerinde birbiriyle etkileşim halindedir. Bilginin oluşumu, kapalı ve açı bilgi arasındaki etkileşimle olmaktadır. Bu etkileşim bilgi dönüşümü olarak ifade edilmektedir (Beijerse, 1999:101).

Bu dönüşümü gerçekleştirecek süreç; literatürde socialization (sosyalleştirme), externalization (dişsallaştırma), combination (bütünleştirme) ve internalization (içselleştirme) kelimelerinin kısaltılması ile ifade edilen SECI (SDBİ) sürecidir. SECI süreci Şekil 2.3.'de görülmektedir. Sosyalleştirme adımı; kapalı bilgiden kapalı bilgiye dönüşümü, dışsallaştırma adımı; kapalı bilgiden açık bilgiye dönüşümü, bütünleştirme adımı; açık bilgiden açık bilgiye dönüşümü, içselleştirme süreci ise; açık bilgiden kapalı bilgiye dönüşümü ifade etmektedir.

Sosyalleştirme; deneyimlerin paylaşılması ve yeni kapalı bilgi yaratılması süreci olarak tanımlanabilir. Bu aşamada tecrübelerin paylaşılması söz konusudur. Çünkü kapalı bilgi genellikle zaman ve mekâna özgü olup formüle edilmesi zordur. Kapalı bilgi aynı ortamda yaşamak ve beraberce zaman geçirilmekle, deneyimlerin paylaşı1ması yoluyla elde edilir (Nonaka ve diğ., 2000:9). Bu durumda sosyalleşme grup davranış ve ilişkileri, örgüt kültürü gibi örgütün sosyal boyutu ile ilgili bir süreçtir. Çalışanlar kapalı bilgiyi, tamamen örgütün sosyal boyutunda kişiler arası ilişkiler ile öğrenir. Kişiler arası öğrenmeler, yazılı ve sözlü kurallara göre değil tamamen gözlem ve taklide dayalı işlemektedir.

Dışsallaştırma; kapalı bilginin açık bilgi ya da somut bir kavram şeklinde ifade edilmesidir. Bilgi yaratma sürecinde kapalı bilginin açık hale dönüşmesi bilginin, prosedürler, talimatlar, hipotez veya kavram şeklini almasıdır. Kapalı bilginin açı bilgi

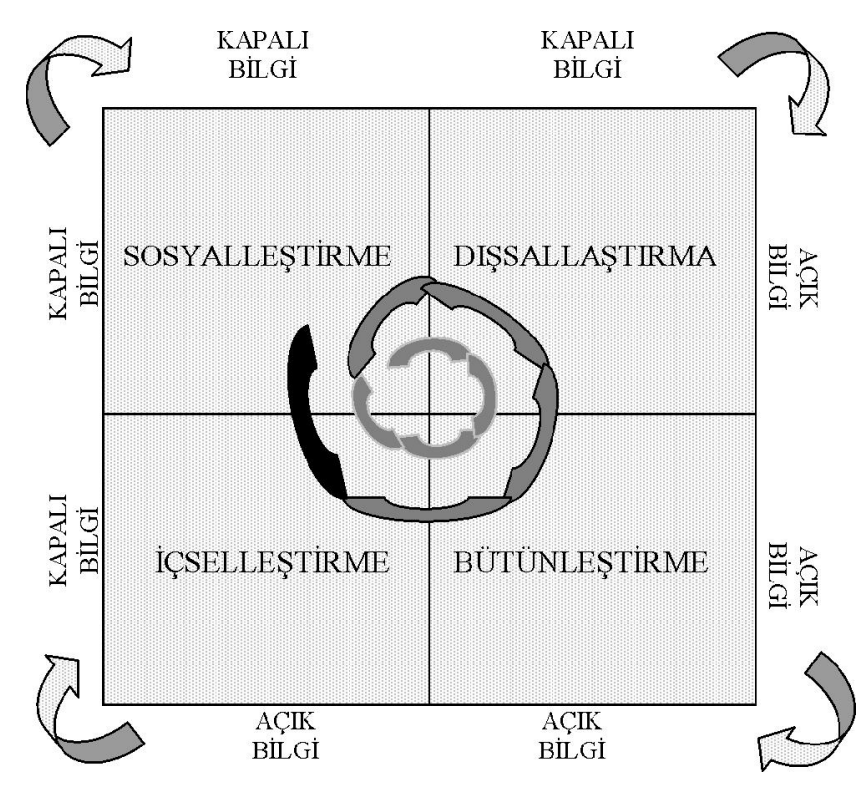

Şekil 3: SECI Bilgi Dönüşüm Süreci (Kaynak: Nonaka vd.-2000, s;72) 
şeklinde ifade edilmesi bilginin berraklaşmasını sağlar. Böylece berraklaşan bilgi başkalarının kullanımına sunulur ve yeni bilgi üretimine zemin oluşturulur (Nonaka ve Takeuchi, 1995:69).

Bütünleştirme; farklı şekillerdeki açık bilginin senteze ulaştırılması olarak tanımlanmaktadır. Bu adım farklı şekillerdeki bilgilerin bir araya getirilerek yeni bilgi oluşturulmasının sağlandığ 1 adımdır. Bilgi bu adımda yeniden kategorize edilir, sıralanır, yeni bilgiler eklenir ve sentez sonucu yeni bilgi elde edilir (Beijerse, 1999:101).

İçselleştirme; bu adım açık bilginin kapalı bilgi olarak somut hale getirilmesini ifade etmektedir. İçselleştirme ile yeni üretilmiş olan açık bilgi örgütün bütünü tarafından paylaşılır. Paylaşılan yeni bilgi kişilerin kullanması ile kişilerde içselleşerek kapalı bilgi haline gelir. Bu yaparak öğrenme ile yakından ilişkilidir (Nonaka ve Takeuchi, 1995:69).

Nonaka ve Takeuchi (1995:69), örgütsel bilginin yaratılması için bireysel düzeydeki ihtiyaçlarda toplanmış olan kapalı bilginin diğer kişilerle sosyalleştirilmesi durumunda yeni bir yaratma döngüsünün başlayacağını ifade etmektedirler. Bu kapalı ve açık bilgi arasındaki sürekli etkileşimi tetikleyecek ve bu etkileşim dinamik hale gelecektir. Bu nedenle SECI süreci Şekil-3'te de görüldügüü gibi, süreç bittiğinde yeni bir süreci tetiklediği döngü şeklinde işlemektedir.

\subsubsection{Bilgi Üretimi İçin Paylașılan Ortam: "Ba"}

Bilgiyi yaratmak için fiziksel bir ortama ihtiyaç bulunmaktadır. Bu ortam literatürde "Ba" olarak adlandırılmaktadır. İlk olarak Japon filozof Kitara Nishida tarafından ortaya atılan ve bilgi felsefesini temel alan ba kavramı Shimizu tarafından geliştirilen bir kavramdır. Ba, bilgi ve deneyimlerin paylaşıldığ 1 alan olarak tanımlanmaktadır (Nonaka ve diğ., 2000:40).

Japonca bir kelime olan ba, sadece fiziksel bir yer anlamında değildir, belirli bir zaman ve alan anlamina da gelir. Bu kapsamda ba zaman-alan bağlantı noktasıdır. Bu durumda bilgi üretimi için paylaşılan ortamlar içerisinde; çalışma alanı ve ofis gibi fiziksel alanlar, telekonferans, e-posta gibi sanal alanlar ve tecrübe, düşünce, idealler gibi zihinsel alanlar ile bunların kombinasyonundan oluşan alanlar yer almaktadır (Nonaka ve diğ., 2000:14-15).

Ba'nın anlaşılmasındaki en önemli nokta karşılıklı etkileşimdir. Bilgi, tek başına çalışma şeklinden daha çok kişiler arası etkileşim ya da kişiler ve çevreleri arasındaki etkileşim yolu ile yaratılır. Bilgi üretim sürecinde ba normal bireysel etkileşimden farklı bir konuma sahiptir (Nonaka ve Konno, 1998:41).

Ba'nın sürekli değişen ve karmaşık bir yapisı bulunmaktadır ve bireyler arasında etkileşimin oluşabilmesi için kendi sınırlarını çizmektedir. Ancak bu sınırlar aynı zamanda dışa da açıktırlar. Kişi sınırlar dışına çıkıp geri gelebilir. Ba içerisinde kişiler zamanı, alanı ve ortak bir dili paylaşırlar. Bu haliyle ba yeni bilginin yaratıldığ 1 canlı ve dinamik bir platformdur (Nonaka ve diğ., 2000:14-16).

Bu durumda ba bilgi için bir platform sağlamaktadır. Bu platform enformasyonun yorumlandığ 1 ve bilginin yaratıldığ platformdur. Medya ve networkde yerleşik olan enformasyon somuttur. Buna karşıllık bilgi ba'da yerleşiktir ve soyuttur. Bu çerçevede bilgi ba'dan ayrı tutulursa enformasyona dönüşür. Ba'nın bu özelliği, bilgi yaratılmasında ve geliştirilmesinde ona önemli bir rol yüklemektedir (Nonaka ve Konno, 1998:41).

Şekil 2.4.'de görülebileceği gibi, ba'nın 4 biçimi bulunmaktadır. Bunlar; yaratıcı ba, iletişimci ba, sistemleştirici ba ve uygulayıc1 ba'dır (Nonaka ve Konno, 1998:46-47; Nonaka ve diğ., 2000:15-17; Nonaka ve Toyomo, 2003:7-9).

Yaratıcı ba: Bireysel ve yüz yüze etkileşimlerin meydana geldiği bu ortamda kapalı ve açık bilgi arasındaki sosyalleşme olur. $\mathrm{Bu}$ alan kişilerin tecrübe, duygu, his ve zihinsel modellerini paylaştığı uygun bir alandır.

İletişimci ba: Kolektif ve yüz yüze etkile- 
şimin meydana geldiği bu alan yaratıcı ba ile kıyaslandığında daha bilinçli yapılmaktadır. Bu aşamada bilgi yaratacak takımlar için nitelikli ve yetenekli doğru insanların seçilmesi önemlidir. Kişiler bu alanda bilgi, beceri, deneyim, zihni modellerini paylaşırlar ve somutlaştırırlar. Kapalı bilginin açık bilgiye dönüşümü bu şekilde sağlanmış olur.

Sistemleştirici ba: Etkileşimin gerçek yer ve zaman yerine sanal dünyaya dönüştüğü bu alan sayesinde bütünleşme evresi oluşur. $\mathrm{Bu}$ aşamada yeni açık bilgiyle ortaya çıkan enformasyonun bütünleşmesi ile bilgi meydana gelir.

Uygulayıcı ba: Kapalı bilginin açık bilgiye dönüşümünü kolaylaştıran uygulayıcı ba'da bilginin içselleşmesi söz konusudur. Simülasyon uygulamaları, yazılı ve görsel iletişim araçları vasıtasıyla ortaya çıkan açık bilgi somutlaşır. İletişimci ba bunu düşünsel olarak gerçekleştirirken, uygulayıcı ba faaliyetten kaynaklanan yansıma ve sinırların ilerisine geçişi sentez haline getirir.

\subsubsection{Bilgi Varlıkları:}

Bilgi üretim sürecinin temelini teşkil eden bilgi varlıkları süreç açısından büyük önem taşımaktadır. Bilgi varlıkları, sadece örgüte has ve örgüt için hayati önem taşıyan varlıklardır. Bilgi varlıkları, bilgi üretim sürecinin girdi, çıktı ve uyumlaştırıcıları olarak rol al- maktadır (Nonaka ve Takeuchi, 1995:71).

Bilgi varlıkları; deneyimsel, kavramsal, sistematik ve rutin bilgi kaynakları olmak üzere 4 şekilde sınıflandırılmaktadır. Deneyimsel bilgi varlıkları; kişisel beceri ve knowhow'lar, önemseme, sevgi, güven ve güvenlik, enerji hurs ve gerilim gibi ortak deneyimlerle paylaşılan kapalı bilgiden oluşmaktadır. Kavramsal bilgi varlıkları; ürün kavramları, dizayn ve marka hakkı gibi imgeler, semboller ve dil yoluyla somutlaştırılmış açık bilgiden oluşmaktadır. Sistematik bilgi kaynakları; dokümanlar, el kitapları, veri tabanı, patent ve lisanslar gibi sistemleştirilmiş ve bütün hale getirilmiş açık bilgiden oluşmuştur. Son olarak rutin bilgi varlıkları ise; günlük çalışmalardaki know-how'lar, örgütsel alışkanlık ve örgüt kültürü gibi faaliyet haline getirilmiş ve faaliyet ve pratiğe yerleştirilmiş ve alışkanlık haline getirilmiş kapalı bilgiden oluşmaktadır (Nonaka ve Trece, 2001:29). Nesnel olarak ölçülmesi zor olan bu bilgi kaynakları aslında örgütün entelektüel sermayesini oluşturmaktadır.

\subsection{Bilginin Depolanması/Organize Edilmesi:}

Örgütler elde ettikleri bilgiyi tekrar kullanabilmek için depolamaya yani saklamaya ihtiyaç hissederler. Bilgiyi saklama, örgütün elde ettiği bilginin kaybını sıfıra indirecek,

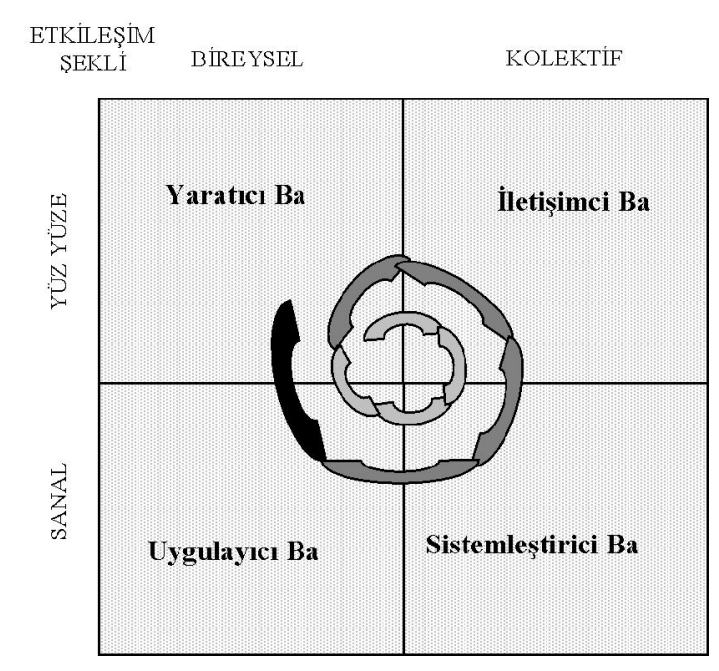

Şekil 3: Ba'nın Dört Biçimi (Kaynak: Nonaka vd., 2000, s;9) 
bilgiye ihtiyaç duyan kişi ve birimlere de istedikleri bilgiye istedikleri zaman ulaşma olanağ1 taniyacaktır. Elde var olan enformasyon ve bilgilerin, kapalı bilginin açı̆̆a ç1karılmasında kullanılıyor olması, bilginin depolanması ve saklanması yoluyla ihtiyaç duyan kişi ve birimlere iletilmesini önemli kilmaktadır.

Depolanan bilgilerin örgütsel ihtiyaçlara uygun şekilde organize edilmesi gerekmektedir. Bu faaliyet enformasyonun tasnif edilmesi, kategorize edilmesi, listelenmesi ve kullanıma uygun hale getirilmesi demektir. Yoksa bilginin düz bir şekilde düzenlenmeden, ihtiyaca, kullanıma ya da kullanan kişiye uygun olmayan şekilde depolanması ve sunulması fayda sağlamayacaktır. Bennett ve Gabriel de (1999:214); bilginin örgüt üyelerine ulaştırılabilmesi için kullanılabilir hale getirilmesi, dokümantasyon ve elektronik süreçlerle kodlanmasının yani bilginin organize edilmesinin gerekli olduğunu ifade etmektedirler.

Bireyler ve örgütler enformasyonu, değişik şekillerdeki bellek sistemlerinde saklarlar. Bu sistemler, beyindeki özel bölümden, bilgi fişlerine, sabit disklere, dosyalama kabinlerine, kütüphane ve veri ambarlarına kadar dayanmaktadır (Despres ve Chauvel, 1999:111). Bilgi yönetimi açısından depolamada kişilerin beyinlerinde olan kapalı bilginin depolanması değil, açı ve kaybolmaya müsait bilgilerin depolanması söz konusudur. Zaten bilgi yönetimi, beyinlerdeki kapalı bilginin açığa çıkarılmasını, açığa çıkan bilgilerin depolanarak diğerleri ile paylaşılmasını ve yeni bilgiler yaratılarak örgütsel süreçlerde kullanılmasını öngörmektedir.

$\mathrm{Bu}$ anlamdaki depolama işlemi örgütlerde yaygin olarak; internet, intranet, extranet, gibi ağ tabanlı bilişim teknolojileri ile farklı enformasyon teknolojileri ve yazılımları bir arada kullanarak oluşturulabilen bilgi yönetim sistemleri aracılığıyla yapılmaktadır.

Bilgi yönetim sistemleri; örgütlerde bilgi toplama, dönüştürme ve dağıtma işlevlerini icra eden insan kaynakları, bilgisayar ve network gibi bilgi teknolojileri ile prosedürler dizisidir. Başka bir değişle bilgi yönetimi sistemi; belirli hedefleri karşılamak üzere verileri kullanıcı/karar verici için anlamlı enformasyona çeviren insangücü, program ve yönetsel süreçlerden oluşan bir faaliyetlerdir (Öğüt, 2003:126).

\subsection{Bilginin Dă̆ıtılması/Paylaşılması:}

Bilginin dağıtılması ve paylaşılması, bilginin bir kişi, grup ya da birimden diğer kişi, birim ya da örgüte transfer edilmesi, yayılmas1 faaliyetidir (Lee, 2001:324). Bu faaliyette temel amaç, örgütteki bütün bireylerin ve birimlerin bilgiye erişebilmelerini sağlama ve bunlar arasinda bilgi transferini olabildiğince kolaylaştırmaktır (Davenport ve diğ,. 1998:46). Örgütlerde bilginin ara sıra ya da rastgele paylaşılması söz konusu değildir. Bilgiye sahip olanların bu bilgiyi kimle ve ne zaman paylaşacakları ya da örgütsel bilginin ne şekilde ve kimlere dağıtılacağ 1 çok önemlidir (Andrews and Delehaya, 2000:795). Bu nedenle bilgi yönetiminde büyük önem taşıyan doğru bilginin, doğru insanlara, doğru zamanda dağıtımı (Beijerse, 1999:167) belli bir mekanizma dâhilinde yapilmalıdir.

Ancak burada özellikle bilginin paylaşıması ile dağıtılması arasındaki farkı belirtmekte fayda vardır. Bilginin dağıtılmasında bilginin diğer kişilere transferi söz konusudur ve hedefine ulaşıp ulaşmadığ 1 kontrol edilmeyebilir. Bilgi paylaşımında ise; bilginin bizzat alıcısına aktarılması söz konusudur. Bilginin transferi kolayken paylaşılması zordur. Dağıtılan bilgi, daha çok enformasyon boyutundaki bilgiden, paylaşılan bilgi ise kapalı yönü fazla olan soyut bilgiden oluşmaktadır. Burada usta-çırak ilişki ile bilgi aktarımı ön plana çıkmaktadır.

Örgütler; daha çok bilgiyi, daha çok kişiye kademe farkı gözetmeksizin transfer etme ortamını sağlayacak bir bilgi dağıtım mekanizması oluşturmalı, çalışanlar bu mekanizma sayesinde; iş akışı, prosedürler, istatistikler, verimlilik, diş çevre, örgüt stratejisi gibi konulardaki bilgiye kolayca erişe- 
bilmeli, ürettiği bilgiyi diğer personelle paylaşabilmelidir. Özellikle oluşturulacak bilgi sistemleri bu konuda etkin bir bilgi dağıtım mekanizması görevi görecektir. Gerçekten bugün örgütlerde bilgi paylaşımı ve transferi için bilgi yönetimi sistemleri kullanılmaktadır. Ancak her bilginin yazılı, elektronik olarak bir bilgi sistemi üzerinden dağıtılamayacağı, gerektiğinde bilginin bizzat üreteni tarafından paylaşılması gerektiği de bir gerçektir.

Örgüt içindeki yazılı, sözel ve görsel raporlar, bültenler, ziyaretler, çalışan rotasyonu ile eğitim ve geliştirme programları ve standardize programları gibi örgütsel araç ve süreçler bilgi dağıtımı ve paylaşımını desteklemektedir (Garvin, 1993:87). Bu tür iletişim araçları ile örgütsel uygulamaların da bilgi yönetimi sistemleri ile entegre edilmesi etkin bir bilgi dağıtım ve paylaşımını doğuracaktır.

Örgütler, biçimsel olarak oluşturulmuş bu bilgi dağıtım ve paylaşım mekanizmalarının dişında informal yöntemlerle de bilgi paylaşımını sağlayacak ortamlar oluşturmaktadirlar (Davenport ve Prusak, 2001:135). Sohbet odaları tarz1, her hangi bir gündem, amaç, konu, problem çözümü gibi bir faaliyeti öngörmeyen bu uygulamalar, bilginin paylaşımını resmi olmayan daha rahat ortamlarda örgüt için değer yaratacak yeni bilgilerin üretimini tetikleyecek paylaşımı sağlamaktadır.

Örgütün sağladığ informal bilgi paylaşım ortamları dışında kişiler kendi aralarında informal bilgi paylaşımında bulunabilmektedirler. İnformal bilgi paylaşım1, herhangi iki kişi ya da bir grup arasinda tesadüfen gelişen ya da belli şartlara bağlı olmadan bir sohbet sırasında kendiliğinden gerçekleşen bilgi paylaşım şeklidir. Bu paylaşım, yüz yüze olabileceği gibi email gibi diğer iletişim araçları ile de olabilmektedir (Yeniçeri ve Demirel, 2006:254).

Bilgi paylaşımında önemli bir diğer konu da bilginin bizzat üreten kişiler tarafından paylaşılması konusudur. Yapılan araştırmalar, bilgiyi üreten kişinin bilgiyi bizzat ak- tarması ve diğer kişiler tarafından kullanılmasının daha faydalı olduğunu göstermektedir (Zaim, 2006). Bilginin veri ve enformasyona göre soyut bir varlık olması paylaşılmasını zorlaştırmakta ve bazı yönleri ile aktarılamaması sorununu doğurmaktadir. Veri ve enformasyonun aktarılması kolay, bilginin ise zor olmaktadır. Öyleyse bilgi paylaşımında bilginin her yönüyle aktarılabilmesi için üreten ya da bilgiyi organize eden kişi tarafından paylaşılması önem arz etmektedir.

Günümüzde bilgili insanlar, organizasyon ve toplumlar için ayrı bir yer ve öneme sahip olmaya başlamıştır. Burada önemli olan bilgilerin insanların beyinlerinde gizli kalması değil, açığa çıkarılıp paylaşılmasıdır (Şerbetçi, 2001:330). Bilgi paylaşıldıkça çoğalan bir değer olup, mevcut bilgiden hareketle "yeni bilgi" yaratılması söz konusu olduğundan "bilginin paylaşımı" bilgi yönetiminde üzerinde önemle durulması gereken bir konudur.

\subsection{Bilginin Kullanılması/Uygulanmast:}

Bilgi yönetim sürecinin son aşaması bilginin kullanılması ya da uygulanması aşamasıdır. Bu aşama, örgütün sahip olduğu bilgileri örgütsel hedef ve amaçlara ulaşmak doğrultusunda kullanılmasıdır. Buna örnek olarak, eldeki mevcut bir bilginin yeni ürün yaratılmasında veya var olan ürünün geliştirilmesinde kullanılması ile yeni bir bilginin bir örgütsel süreç ya da prosedüre uygulanmasını gösterebiliriz.

Bilginin uygulanarak değerinin arttırılabilmesi için, çalışanların davranışlarında, çalışma anlayış ve biçimlerinde olumlu yönde değişime yol açması, yeni ve faydalı fikirlerin, süreçlerin, uygulama ve politikaların geliştirilmesi konusunda somut katkılar sağlaması gerekmektedir. Bu ise bilginin, örgüt yararına etkili ve sonuç getirecek şekilde kullanılmasını gerektirmektedir. Bu açıdan bilginin kullanılması ve örgüt için faydalı davranışlara dönüştürülmesi, o bilginin elde edilmesi kadar önemlidir. Diğer taraftan bilginin uygulama aşamasının başarısı, bilginin ne ölçüde etkili kullanıld1- 
ğına, bu bilginin ne ölçüde davranışlara yansıdığına ve uygulamaya geçirildiğine bağl1dir (Zaim, 2006).

Bilgi örgütün ürün ve hizmetlerine yerleştirilebilir. Bilgiyi alan çalışanlar uzmanlıklarını bu bilgiyi kullanarak bir süreç ya da ürün geliştirmek için kullanabilirler. Hemen hemen her üretim süreci, kişilerin beyninde var olan bilgi ile oluşturulur (Davenport ve Prusak, 1998:124). Bilgi paylaşıldıkça çoğalmakta ve kendini yenilemektedir. Ancak salt bilgi bir şey üretemez, yalnızca bir görevle bütünleştiğinde üretken olabilir (Öğüt, 2003: 18). Öyleyse yeni bilgiler, kişilerin beynindeki kapalı bilgileri açığa çıkaracak şekilde örgütsel süreç ve ürünler için uygulanırsa bilgi etkin bir şekilde kullanılmış olacaktır.

Bilginin uygulanması veya kullanılması sonucunda da örgütler yeni bilgi yarat1minda bulunabilirler. Elde edilen yeni bilgi ile süreç yeniden devam edecektir. Bu durum 4 aşamadan oluşan ve bilginin elde edilmesi ile başlayan bilgi yönetim sürecinin bir döngü şeklinde olduğunu ve dinamik bir nitelik taşıdığını göstermektedir. Bilginin kullanılarak yeni bilgi üretilmesi, yeni bilgiler üretilmesi için süreci tekrar başlatacak, böylece örgütsel bilgi yönetimi süreci ile elde edilen bilgiler bir döngü dahilinde yeni örgütsel bilgilerin üretilmesine olanak sağlayacaktır. Bu aşama, bilginin örgütçe özümsenerek örgütün bilgisi haline getirilmesi aşaması olduğundan yani bilgi, bu aşamada örgütsel süreçlere, ürünlere, uygulama ve metodlara yansitıldığından örgütsel öğrenme gerçekleşmektedir.

\section{5. Örgütsel Bilgi Yönetiminin Öğrenen Organizasyon Yazınındaki Yeri: Bilgi Yönetimi-Örgütsel Öğrenme İlişkisi:}

Bilgi Yönetim Sürecinin bilginin kullanılması/uygulanması aşamasında da görüldüğü gibi örgütler, öğrendikleri, elde ettikleri ya da yarattıkları bilgiyi özümsemekte ve örgütsel çıtıllara uygulanarak yeni bilgilerin yaratılmasını sağlamaktadırlar. Bu durum bireysel öğrenmenin değil örgütsel öğrenmenin bir sonucudur. Bu nedenle bilgi yönetim süreci örgütsel öğrenmeyi içine al- maktadır. Öğrenen organizasyon ile ilgili yapılan çalışmalarda öğrenen organizasyona dönüşebilmek için ögrrenen bireyler yaratma-ögrrenen takımlar yaratma-örgütsel öğrenme yaratma'nın gerekliliğinden bahsedilir. Ancak bu noktada bireysel öğrenilen bilgilerin örgütsel öğrenmeye dönüşmesinde bilgi yönetiminin etkisi üzerinde durulmamakta, ögrrenen organizasyonların bilgi yönetimi yeteneğine sahip olduklarını ifadeyele yetinilmektedir. Oysa ki; ögrrene organizasyon-bilgi yönetimi-örgütsel öğreneme kavramları birbiri içine geçmiş, sinerjik ve tamamlayıcı kavramlardır. Bu nedenle kavramlara ilişkin bir hiyerarşi ortaya konulmamıştır.

Bazı araştırmacılar öğrenen organizasyonun bir yeteneği olan bilgi yönetimini örgütsel öğrenme ile aynı süreçler olarak ele alırken bazıları ise bilgi yönetimi ya da örgütsel öğrenme kavramı altında bir bütün olarak ele almaktadırlar. Kanımızca konuya bilgi yönetimi açısından bakıldığında örgütsel öğrenmenin gerekliliği, örgütsel öğrenme açısından bakıldığında bilgiyi yönetmenin gerekliliği, konuyu farklı açılardan ele alan araştırmacılara farklı bakış açıları kazandırmiştır.

“Bilgi yönetim süreci”ne benzer bir süreci Dixon örgütsel öğrenme için oluşturmuştur. Dixon'a göre bilginin yaratılması, bilginin örgüt bazında yayılması, bilginin içselleştirilmesi ve içselleşen bilginin kullanılmasından oluşan "örgütsel öğrenme süreci" ile örgütler yeni bilgiler üretebilecektir (Dixon1994, s;46). Örgütsel öğrenme, yeni örgütsel bilgi üretiminin önünü açıcı bir niteliğe sahiptir. Örgütsel bilgi, sürekli değişen bir yapıya sahiptir ve bu değişimler bir ürün olarak örgütsel öğrenmeyi ifade etmektedir. Örgütsel öğrenme sürecinde gerçekleşen karmaşık işlemler ve örgüt dışı aktörlerin de içinde yer aldığ 1 etkileşimler neticesinde yeni örgütsel bilgi üretimi mümkün olmaktadır (Kalkan, 2005:404). Bu durumda örgütsel öğrenme, bilgi yönetiminin bilginin elde edilmesine katkı sağlayan bir alt unsuru olmaktadır. Naktiyok da (2004:196), bilgi yönetimini etkileyen faktörleri incelerken 
örgütsel öğrenmeyi bilgi yönetiminin alt bir unsuru olarak göstermektedir.

Daha önce öğrenen bir organizasyon olabilmek için bilginin yönetilmesine, bilgiyi yönetebilmek yani; bilgiyi paylaşmak, kullanmak ve yeni bilgi yaratmak için ise öğrenen bir örgüt olmaya ihtiyaç bulunduğu ifade edilmiş, bilgi yönetiminin öğrenen organizasyonun önemli bir kabiliyeti olduğu üzerinde durulmuştu. Her ne açıdan bak1lırsa bakılsın bilgi yönetimi ile öğrenen organizasyon kavramları birbiri ile ilişkili iki önemli kavram olmakla birlikte ikisinin birlikte sinerji yarattıkları da önemli bir gerçektir.

Bilgi yönetimi, öğrenen organizasyonun alt bir unsuru olmasına rağmen özellikle bilgi sistemleri ve bilgi teknolojilerinin gelişmesi nedeniyle daha çok ön plana çıkmış ve tamamen farklı ve bağımsız bir uygulama gibi algılanmaya başlamıştır (Loermans, 2002:289). Bilgi yönetimini, öğrenen organizasyondan tamamen ayrı bir faaliyet olarak nitelemek yanlış olacaktır. Ancak burada bilgi yönetiminin öğrenen organizasyon aç1sindan çok önemli bir faaliyet olduğunu ve öğrenen organizasyon olmada önemli bir aşama olduğunu belirtmekte fayda bulunmaktadir.

Swan 1990 ile 1998 y1lların kapsayan incelemesinde; bilgi yönetimi ile ilgili araştırmaların sayısında ciddi bir artışın olduğu, bu artışın öğrenen organizasyonla ilgili araştırma sayısını geride bıraktığını ifade etmektedir. Hatta bilgi yönetiminin, öğrenen organizasyon gelişiminde son olmadığını, ancak öğrenen organizasyondan saptığını iddia etmektedir. Burada bilgi yönetiminin öğrenen organizasyondan ayrılarak ayrı bir eksene kaydığını söylemek doğru olmayacaktır. Loermans'ın ifade ettiği gibi bu disiplinler arasında belirli bir sinerji olduğunu ve bu iki disiplinin daha büyük bir eksende buluştuğunu söylemek de doğru olacaktır (Loermans, 2002,:289).

Örgütlerde bilginin yönetimi, bir örgütün daha zeki bir şekilde faaliyet göstermesini sağlayan ve örgütsel performansı iyileştiren örgüt bilgisinin yönetimidir. Örgütsel anlamda zekâ; yararlı ve zamanında bilgi yaratacak şekilde veri elde etme, analiz etme ve yorumlama kabiliyetini yansitır. Emsallerinden daha hizlı ögrenebilen ve bilgiyi yaratabilen bir yapıya sahip olan zeki örgütler öğrenme hakkında öğrenir, böylece yeni bilgi bulma ve uygulama sürecini hizland1rırlar (İşcan ve Naktiyok, 2005:87). Bir örgütteki bilgi üretiminin sonuçları, o örgütün sahip olduğu bilgisini ve yeterliliğini sürekli olarak artıracak ve böylece o örgüt öğrenen organizasyon görünümüne kavuşacaktır (Loermans, 2002:290). Gerçekten bilgiyi yönetebilen örgütler öğrenmeyi öğrenerek öğrenen organizasyon haline gelmektedirler. Bir yandan sürekli öğrenip yeni bilgiler üretebilmekte, bu yeni bilgiler ışığında yenilikler yaratabilmektedirler. Böylelikle bilgi yönetimi ile öğrenen organizasyon olma örgütte bir sinerji yaratmaktadır.

Öğrenen organizasyon adı altında gelişen kavram ve uygulamalar büyük ölçüde bir bütün olarak örgütlerin, rekabet güçlerini artıracak tarzda bilgi yaratma ve kullanma yeteneklerini geliştirmesine yönelmiştir (Koçel, 2003:437). Bu nedenle bilgi yaratma, paylaşma ve örgüte artı değer katacak daha çok yeni bilgi yaratma süreci olarak bilgi yönetimi öğrenen organizasyonun en önemli alt unsurudur. Naktiyok (2004:210-213) bilgiyi, öğrenen organizasyonun önemli bir alt sistemi olarak görmekte ve bilgi yönetimini örgütsel öğrenmeyi hızlandıran bir faktör olarak değerlendirmektedir.

Geçmişte bu konu ile ilgili farklı bakış açıları olmuştur. Düşünürler, öğrenen organizasyonu zamanla açıklık kazanan bir süreç olarak görmüş ve öğrenen organizasyon ile bilgi edinimi ve performans artması arasında bağlantı kurmuşlardır. Bu çerçevede bazıları davranış değişikliğinin öğrenme için gerekli olduğuna inanmakta; bazıları yeni düşünce ve yaklaşımların yeterli olduğunda ssrar etmektedir. Bazıları enformasyon işleme sürecini öğrenmenin gerçekleşmesini sağlayan mekanizma olarak görmekte; kimileri ortak kavrayışları, örgütsel rutinleri, hatta belleği ortaya çıkarmaktadır. Diğer 
bazı araştırmacılar, örgütsel öğrenmenin yaygın olduğunu düşünürken, başkaları ise öznel hatalı yorumların esas olduğuna inanur. Öğrenen organizasyon; bilgiyi yaratma, edinme ve aktarma, yeni bilgi ve kavrayışları yansıtmak için davranışını değiştirme becerisine sahip olan örgüttür. $\mathrm{Bu}$ tanım basit bir temele dayanır; öğrenme gerçekleşecekse yeni fikirler yani bilgiler gerekir. Bu bilgiler kimi zaman örgüt içinden kimi zamansa örgüt dışından gelir (Yeniçeri, 2006:183-184). O halde öğrenen organizasyonun temel faaliyeti olan "öğrenme" nasıl gerçekleşirse gerçekleşsin temelde "bilgi" gereklidir. İşte bilgi yönetimi; öğrenme için gerekli olan bilgiyi bulma, temin etme, derleme, yaratma ve ihtiyacı olana iletme anlaminda rol üstlendiğinden öğrenen organizasyonun diğer alt unsurlarından farklı olarak öğrenen organizasyonun sinerjik unsurudur.

Öğrenen organizasyon rekabetçi avantaj için gerekli bilgiyi yaratır fakat bu durum bilginin yeterli ve etkili kullanıldığı anlamina gelmez. Bilgi yönetimi disiplini, öğrenen organizasyondan çıtıları alır, onu yönetir ve çevreye uygun olarak yenilenmeyi sürdürdüğünden ve bilgi varlığının mevcudiyetini koruduğundan emin olur. Bilgi yönetimi ve öğrenen organizasyon kaçınılmaz bir şekilde birbirine bağlıdır ve birisi olmadan diğeri hayatta kalamaz. Bilgi yaratma, bilgi yönetimi ve öğrenen organizasyon disiplinlerinde temel faktördür ve iki disiplin arasındaki sinerjinin temel alanını gösterir (Loermans, 2002:290-293). İki disiplinde ortak nokta olan bilgi yaratmanin bu konumu, öğrenen organizasyon ile bilgi yönetiminin büyük bir eksende buluştuğunu ve sinerji yarattığını göstermesi açısından önemlidir.

O halde diyebiliriz ki; bilgi yönetimi daha geniş bir kavram olan öğrenen organizasyon kavraminın altında bir uygulamadı. Bilginin elde edilmesi, depolanması, paylaşılması ve kullanılmasını içeren bilgi yönetimi; öğrenen organizasyonun bir alt sistemi ve öğrenen organizasyon olmayı hızlandıran faktörler arasında yer (Naktiyok, 2004:213) aldığından bilgi yaratma ve paylaşma faaliyeti olan bilgi yönetiminin, öğrenen organizasyonun temel yeteneklerinden birisi olduğu (Yazıc1, 2001:154) çok açıktır.

Özetle ifade edecek olursak; örgütsel öğrenme ile birlikte bilgi yönetimi öğrenen organizasyonun sahip olduğu yeteneklerdir. Ancak burada "öğrenen organizasyon olmak" için bilgiyi yönetebilmenin, "bilgiyi yönetebilmek" için ise örgütsel öğrenmenin, gerekli olduğunu ve örgütsel öğrenme ile öğrenen organizasyonun aynı şey olmad1ğını da özellikle belirtmekte fayda bulunmaktadır. Bu çerçevede öğrenen organizasyon, bilgi yönetimi ve örgütsel öğrenmeyi içine alan daha geniş bir kavramdır. Burada söz konusu olan öğrenme, örgütsel anlamdaki bir öğrenme faaliyetidir. Örgütsel öğrenme, bir örgütün alt unsurlarında öğrenilenlerin örgüt geneline yayılması ve kabul görmesi ile olasıdır. O halde bilgi yönetimi örgütsel öğrenmeyi içine alan bir kavramdir. Bu üç kavramın birbiri ile olan hiyeraraşisi tepe noktada öğrenen organizasyon olacak şekilde; Öğrenen Organizasyon-Bilgi Yönetimi-Örgütsel Öğrenme şeklindedir.

\section{SONUÇ:}

Bugün örgütlerin içinde olduğu ortam; örgütlerin bilgiyi elde etme, kullanma ve yeni bilgiler yaratma konusunda hizlı olmalarını zorunlu kılmaktadır. Öğrenen organizasyon olma, küreselleşmenin hızlandırdığı değişim ortamına ve yeni rekabet şartlarına ayak uydurabilmek için örgütlere imkan sunmaktadır. Çünkü öğrenen organizasyon, hem bilgiye ulaşma, yeni bilgi yaratma, bilgiyi kullanma, mobilize etme, hem de yeni bilgi ve kaynağı karar ve davranışlara yansıtmada yani örgütsel öğrenmede yetenekli örgüttür. Öğrenen bir örgütün temel yeteneği olarak bilgi yönetimi, örgütlerin bilgi çağının gerektirdiği bilgi rekabetinde geri kalmamalarını sağlamaktadır. Burada önemli olan, örgütlerin bilgi yönetim sürecini işletebilmeleridir. Sağlıklı bir bilgi yönetim sistemi ile örgütsel bilgiyi yönetebilen örgütler, örgütsel öğrenme ile rekabetin ge- 
rektirdiği bilgi ihtiyacını karşılayabileceklerdir.

Bilgi yönetim süreci; sistematik olarak bilginin elde edilmesi, paylaşılması ve kullanılarak örgütsel çıktılara dönüştürülmesini garanti altına alan bir süreçtir. Eğer örgütler, örgütsel bilgiyi bilgi yönetim sürecini işleterek yönetebilirlerse öğrenen organizasyon olabileceklerdir.

Bu araştırmada, öğrenen organizasyon ile ilişkili ve birbirinden farklı olan örgütsel öğrenme kavramı ve bilgi yönetimi kavramları arasındaki hiyerarşi ve ilişki ortaya konmaya çalışılmıştır. Öğrenen organizasyonun temel faaliyeti olan "öğrenme" nasıl gerçekleşirse gerçekleşsin temelde "bilgi" gereklidir. Bilgi yönetimi; öğrenme için gerekli olan bilgiyi bulma, temin etme, derleme, yaratma ve ihtiyacı olana iletme şeklinde rol üstlendiğinden öğrenen organizasyonun diğer alt unsurlarından farklı olarak öğrenen organizasyonun sinerjik unsurudur. Diğer taraftan bilgi yönetimi; örgütsel öğrenmeyi içinde barındıran bir kavramdır. Bilgi yönetim süreci sistematik olarak bilgi elde edinilmesi ve bunun paylaşılmasını garati altına alırken örgütsel öğrenme ile örgütsel bilgi yarat1mını sağlamaktadır. Bu durumda bu üç kavram, Öğrenen Organizasyon-Bilgi Yönetimi-Örgütsel Öğrenme şeklinde bir hiyeraraşiye sahiptir.

\section{Kaynaklar}

Andrews, K.M. and Delehaya, B.L. (2005), "Influences On Knowledge Process In Organizational Learning: The Psychosocial Fitler", Journal Of Management, 37:6, pp.797-810.

Arslan, D. (2001), Öğrenen Organizasyonlar, İstanbul Teknik Üniversitesi Fen Bilimleri Enstitüsü, Yayınlanmamış Yüksek Lisans Tezi.

Atak, Metin ve Atik, İlhan, (2002) “Örgütlerde Sürekli Öğrenmenin Önemi ve Öğrenen Örgüt Oluşturma Sürecine Etkisi", Havacıllk ve Uzay Teknolojisi Dergisi, 3:1, s.63-70. Barutçugil, İsmet, Bilgi Yönetimi, İstanbul: Karyer Yayıncllik.

Beijerse, Roelof P. (1999), “Questions in Knowledge Management: Defining and Conceptualising a Phenomenon", Journal of Knowledge Management, 3:2. doi:10.1108/13673279910275512

Bennett, Roger and Gabriel, Helen (1999) "Organizational Factors and Knowledge Management Within Large Marketing Departments: An Empirical Study" Journal Of Knowledge Management, 3:3, pp.212-225. doi:10.1108/13673279910288707

Bhatt, Ganesh D. (2001) “Knowledge Management In Organizations:Examining The Interaction Between Technologies, Techniques, and People", Journal Of Knowledge Management, 5:1, pp.68-75. doi:10.1108/13673270110384419

Budak, Gülay ve Budak, Gönül (2004), İşletme Yönetimi, İzmir: Barış Yayınları, 5. Bask1.

Çorbacioğlu, M. (2000), Learning Organization, Marmara Üniversitesi Sosyal Bilimler Enstitüsü, Yayınlanmamış Yüksek Lisans Tezi. 
Daft, Richard L. (2000), Organization Theory and Design, Ohio: Jouth-Western Collage Public, 7th editon.

Davenport, T.H. and Volpel, S.C. (2001), "The Rise of Knowledge Towards Attention Management", Winter, pp.4457.

Davenport, Thomas H. ve Prusak, Laurence (1998), “İş Dünyasında Bilgi Yönetimi: Kuruluşlar Ellerindeki Bilgiyi Nasıl Yönetirler?", Çev: G. Günay, İstanbul: Rota Yayın Yapım, İstanbul.

Davenport, Thomas, Long, David W. and Beers, Michael C. (1998), "Succesful Knowledge Projecets", Sloan Management Review, 39:2, pp.43-57.

Despres, C. ve Chauvel, D. (1999), “Knowledge Management(s)", Journal of Knowledge Management, 3:2, pp.110120. doi:10.1108/13673279910275567

Dixon, Nancy (1994), The Organizational Learning Cycle: How We Can Learn Collectively, London: McGraw-Hill Book Company.

Drucker, Peter F. (1993), Gelecek İçin Yönetim: 1990'lar ve Sonrası, Çev: F.Üçcan, Ankara: Türkiye İş Bankası Yay.

Garvin, David A. (1993), "Building A Learning Organization", Harvard Business Review, 71:4, pp.78-91. PMid:10127041

Gates, Bill, (1999), Dijital Sinir Sistemiyle Düşünce Hızında Çalışmak, Çev: Ali Cevat Akkoyunlu, İstanbul: Doğan Kitapcılık.

Geyik, M. ve Barca, M. (2005), “Etkin Bilgi Üretimi İçin Örgütler Nasıl Tasarlanmalıdır", 3. Ulusal Bilgi, Ekonomi ve Yönetimi Kongresi.

Gupta, B., Anderson, R.E., Tahtam, R.E. ve Black, W.C. (1998), "Knowledge Management: Practices and Challanges", 100:1, pp.17-21.
Guthrie, J. (2000), “Intellectuel Capital Review: Measurument, Reporting and Managemet", Journal of Intellectuel Capital, 1:1.

Hunt, G. Tomas (2003), "An Integration of Thoughts on Knowledge Management", Decision Sciences, 34:2, pp. 189195.

İpçioğlu, İ. ve Erdoğan, Z. (2005), “İşetmelerde Liderlik ve Bilgi Yönetimi Arasındaki İlişkinin İncelenmesine Yönelik Bir Araştırma", 3. Ulusal Bilgi, Ekonomi ve Yönetimi Kongresi.

İraz, R. (2005), “İşletmelerde Bilgi Yönetiminin Yenilik ve Rekabet Gücü Üzerindeki Etkileri", Atatürk Üniversitesi İ̈BF Dergisi, 19:1.

İşcan, Ömer Faruk ve Naktiyok, Atılhan (2005), Dijital Çağ Örgütleri, İstanbul:Beta Yay., 2005.

Jones, G.H., Organizational Theory (2001), Pintice Hall, Third Edition.

Kalkan, Veli Deniz, (2005), “Örgütsel Öğrenme Çalışmalarında Yeni Açılımlar: Örgütsel Zeka ve Bilgi Üretimi", 3. Bilgi, Ekonomi ve Yönetim Kongre Bildirileri, Osmangazi Ünv., 25-26 Kasım 2005, Eskişehir, 2005.

Koçel, Tamer (2003), İşletme Yöneticiliği, İstanbul: Beta Yayıncılık, 9. Baskı, 2003.

Lee, Sang N. (2001), "The Impact of Knowledge Sharing, Organizational Capability and Partnership Qualty on IS Outsourcing Succes", İnformation and Management, 38, pp. 323-335. doi:10.1016/S0378-7206(00)00074-4

Loermans, Josef, (2002), "Synergizing The Learning Organization And Knowledge Management", Journal of Knowledge Management, 6:3, pp.285-294. doi:10.1108/13673270210434386 
Mc Adam, R ve Mc Creedy, S (1999) “A Critical Review of Knowledge Management Modals", The Learning Organizations, 3, pp.91-101.

McGill, Michael E. and Slocum, John W, (1996), "Unlearning the Organization", Organizational Dynamics, 22:2, pp.6873, Autumn.

Myers, Paul S, (1996), Knowledge Management and Organizational Design, Butterworth-Heinenman, Boston.

Naisbitt, J. ve P. Aburdene, (2000), New Directions for the 1990's: Megatrends.

Naktiyok, Atılhan (2004), İç Girişimcilik, İstanbul: Beta Yayıncilık.

Nonaka Ikujirao and Ryoko, Toyomo (2003), "The Knowledge-Creating Revisited: Knowledge Creation As A Synthesizing Process", 1:1, July, Nonaka, Ikujirao and Treece, David (2001), Managerial Industrial Knowledge, London:Sage Publication.

Nonaka, Ikujirao, Ryoko, Toyomo and Noboru, Konno (2000), "SECI, Ba and Leadership: A Unified Model of Knowledge Creation", Long Range Planning, 33:1, February, 2000. doi:10.1016/S0024-6301(99)00115-6

Nonaka, Ikujiro ve Takeuchi, Hirotaka (1995), "The Knowledge Creating-Company", Newyork: Oxford Universty Press, O’Dell, C., Grayson, C.J. ve Essaides, N. (2003), Ne Bildiğimizi Bir Bilseydik, Çev: Günhan Günay, İstanbul: Dışbank Kitapları .

Öğüt, Adem (2003), Bilgi Çağında Yönetim, Ankara: Nobel Yayın Dağıtım.

Özer, Pınar Süral (2005), Toplam Kalite Yönetimi ve Felsefesi, İzmir: Hv.Tek.Ok.K.lı̆̆1 Yayını, 2005.
Pedler, Mike, Burgoyne John ve Boydell Tom (1991), The Learning Company: A Strategy for Sustainable Development, London: McGraw-Hill Book,

Senge, Peter M. (1990), Beşinci Disiplin, Çev.:Ayşegül İldeniz, Yapı Kredi Yayınları.

Skyrme, David J. (2007), Knowledge Management Basics, http:/ /www.skyrme.com/resurce/km basics.htm (19.11.2007).

Şerbetçi, N. Derya (2001), "Bilgi Toplumuna Geçiş Sürecinin İşletme Yönetimi Üzerinde Yarattığ1 Etkiler", Dumlupınar Ünv. Sosyal Bilimler Dergisi, 3:5, s:329351.

Taşkın, E., Sezici, E. ve Oğuz, A. (2001), “Bilgiye Dayalı Eğitim", Dumlupınar Üniversitesi Sosyal Bilimler Dergisi, 3:5.

Toffler, Alvin (1994), Yeni Güçler Yeni Şoklar, Altın Kitaplar, İstanbul.

Von Krogh, V.G. (1998), "Care In Knowledge Creation", California Management Review, 17:3, pp.133-154.

Wilson, Philip (2000), Managing for Knowledge, Scitech Educational, Broadstairs Kent, UK.

Yazıc1, Selim (2001), Öğrenen Organizasyonlar, Bursa:Alfa Yayınları, Yeniçeri, Özcan (2006), "Örgütleri Etkinleştirme Aracı Olarak Bilgi ve Bilgi Yönetimi", Yönetimde Yeni Yaklaşımlar", Editör: Özcan Yeniçeri, İstanbul: Q Kültür Sanat Yayıncilık, s.175-191.

Zaim, Halil (2006), “Bilgi Yönetim Süreçleri", http//www.bilgiyonetimi.org /cmpages/mkl_gos.php?nt=250, 25.03. 2006. 
